\title{
Hur reformer styr verksamhet på fritidshem
}

\author{
Ragnhíld Löfgren, Helene Elvstrand, Magnus Jansson och Håkan Löfgren
}

\section{Linköping University Post Print}

\section{$\$$ Tweet}

N.B.: When citing this work, cite the original article.

Original Publication:

Ragnhíld Löfgren, Helene Elvstrand, Magnus Jansson and Håkan Löfgren, Hur reformer styr verksamhet på fritidshem, Venue, 2016, 1-6.

Publisher: Linköpings universitet, Lärarrummet

Postprint available at: Linköping University Electronic Press

http://urn.kb.se/resolve?urn=urn:nbn:se:liu:diva-129331 


\section{Hur reformer styr verksamhet på fritidshem}

\section{Ragnhild Löfgren, Helene Elvstrand, Magnus Jansson \& Håkan Löfgren}

Det här projektet handlar om vilka reformer på fritidshem som kommer till uttryck i lärares och rektorers berättelser om fritidshem. Vi använder i denna text termen reformer både för att beskriva statliga och kommunala reformer men också mer lokala reformer som utformats på enskilda fritidshem. Projektets övergripande syfte är att beskriva hur olika reformer på fritidshem kommer till uttryck i lärares/rektorers berättelser om vad som styr verksamheten på fritidshem idag.

\section{Vad säger läroplanen om fritidshem?}

Fritidshem har under senare år fått ett tydligare lärandeuppdrag i läroplan och Allmänna råd (Skolverket, 2011; Skolverket, 2014) och kommer under hösten att få ett eget kapitel i läroplanen. I den läroplansremiss som arbetats fram finns framskrivet nyckelord såsom elever (inte barn), undervisning (inte lärande), samt en rad nya mål som fritidshemmet ska beakta (se remiss läroplan, 2015) som bland annat fokuserar på olika typer av ämnesinnehåll. Fritidshemmens centrala uppdrag kan idag beskrivas som att erbjuda barn en meningsfull fritid och stödja och stimulera deras emotionella, fysiska, intellektuella och sociala utveckling (Skolverket, 2014).

Vi menar att ovan beskrivna ändringar i läroplanen samt ändringar i Skolverkets Allmänna Råd (2014) tillsammans med lokala reformer, innebär en delvis förändrad verksamhet i fritidshemmen och att detta behöver belysas och beskrivas för att förstå hur verksamheten på fritidshem ser ut. Parallellt med detta har fritidshemmet kommit likt andra utbildningsinstitutioner fått ökade krav på ett systematiskt kvalitetsarbete (Lager, 2015). 


\section{VENUE}

\section{Vilka reformer styr verksamheten på fritidshem?}

Våra resultat redovisas i tabellen nedan som en sammanställning av de olika reformer som rektorer och lärare berättat om i relation till sin verksamhet på fritidshem. Data baseras på intervjuer med två rektorer och en lagledare på tre olika skolor i en mellanstor kommun samt en intervju med en lärare på fritidshem i en liten kommun i Sverige. I intervjuerna bad vi dem beskriva de reformer som de upplevde berörde deras arbete på fritidshemmet. Syftet med tabellen är att illustrera den reformträngsel som styr verksamheten i fritidshem idag. Dessa reformer utgör en viktig förutsättning för hur skrivningarna om fritidshem $\mathrm{i}$ den nya reformerade läroplanen kommer att tolkas, översättas och 'göras' i framtiden.

I tabellen finns, i kolumnen till vänster, redovisat reformer som vi tolkar som centrala eller statliga reformer. Här hänvisar lärare/rektorer mer direkt till läroplan, skollagen eller andra Skolverkstexter. I kolumnen i mitten redovisas de reformer som vi tolkar som kommunala, det vill säga reformer som omfattar hela kommunen till exempel Fronter, lärandegrupper inom fritidshem där de läser utvald litteratur eller deras beskrivningar av att arbeta med att införa 10-12 års verksamhet i kommunen. Vi beskriver också hur lokala reformer som således handlar om det mer verksamhetsnära görandet eller genomförandet av reformer kommer till uttryck i lärarnas/rektorernas berättelser om verksamheten på fritidshem. Här belyses exempelvis arbete med "fritidsboken", "kompislek" eller pedagogiska planeringar. En del av dessa reformer utgör olika aspekter av övergripande reformer - till exempel kan arbetet med 'synligt lärande' - betraktas som en tolkning av mål i läroplanen eller ibland som en kommunal reform (då under namnet Visible learning) - men vi redovisar här hela listan för att visa bredden och mångfalden.

\section{Tabell 1. Reformträngsel}

\begin{tabular}{|c|c|c|}
\hline Allmänna (statliga) reformer & $\begin{array}{lll}\begin{array}{l}\text { Kommunala } \\
\text { riktlinjer }\end{array} & \text { reformer } & \text { eller } \\
\end{array}$ & Lokala reformer \\
\hline Implementering av målen i Lgr11 & $\begin{array}{l}\text { Fronter - information till föräldrarna } \\
\text { via IT-baserad plattform }\end{array}$ & $\begin{array}{l}\text { Dokumentation och synliggörande, } \\
\text { "fritidsboken", } \\
\text { resultatutvärderingar }\end{array}$ \\
\hline Skollagen & $\begin{array}{llll}\text { Instagram }- & \text { rapporter } & \text { om } \\
\text { verksamheten } & & \\
\end{array}$ & $\begin{array}{l}\text { Pedagogiska planeringar - "våra } \\
\text { policydokument som vi } \\
\text { formulerar, mallar och innehåll" }\end{array}$ \\
\hline
\end{tabular}




\section{VENUE}

\begin{tabular}{|c|c|c|}
\hline Allmänna råd för fritidshem & $\begin{array}{l}\text { Trygghetsteam - enkäter, rutiner och } \\
\text { krisplaner }\end{array}$ & $\begin{array}{l}\text { "Synliggör lärandet" } \\
\text { "Uppmuntra lärandet även på } \\
\text { fritidshem" }\end{array}$ \\
\hline Samverkan med hem och skola & Genusprojekt & "Meningsfull fritid" \\
\hline Delaktighet och inflytande & Kometutbildning & $\begin{array}{l}\text { IKT, Lärplattor, dokumentation } \\
\text { och 'I-movie' }\end{array}$ \\
\hline Åtgärdsprogram & $\begin{array}{l}\text { Övergångar för elever från } \\
\text { internationell klass }\end{array}$ & "Matematik på fritidshem" \\
\hline Mål och utvecklingsplaner & $\begin{array}{l}\text { Förstelärare med inflytande över } \\
\text { fritidshem }\end{array}$ & "Problembeteenden i skolan" \\
\hline \multirow{7}{*}{$\begin{array}{l}\text { Skolverkets text om "övergångar" } \\
\text { (från förskola till skola) }\end{array}$} & Fritidshem ambassadörer & "Socialt samspel" \\
\hline & $\begin{array}{l}\text { Lärandegrupper för fritidshem - } \\
\text { Läser Timperley }\end{array}$ & "Vad lär du dig på fritids" \\
\hline & $\begin{array}{l}\text { Maximalt lärande, likvärdighet, lust } \\
\text { och nyfikenhet }\end{array}$ & "Kompislek" \\
\hline & $\begin{array}{l}\text { Införa 10-12 årsverksamhet för hela } \\
\text { kommunen }\end{array}$ & "Rastverksamhet" \\
\hline & Systematiskt kvalitetsarbete & $\begin{array}{l}\text { "Trygghet, arbetsro } \\
\text { kamratskap" }\end{array}$ \\
\hline & SOL arbete (språkprojekt) & Arbete med lokala IUP:er \\
\hline & Visible learning & \\
\hline
\end{tabular}

\section{Några kommentarer från lärare och rektorer om reformerna}

För att beskriva lite mer ingående hur lärare och rektorer tolkar och arbetar med dessa olika reformer så ger vi också några exempel från intervjuerna. Vid intervjuerna så kommenterade en rektor på en skola egna pedagogiska planeringar och sammanhangen mellan läroplan och att "synliggöra lärande" på fritidshemmet på följande vis:

Rektor: Ja det gör de [syftar på egna pedagogiska planeringar] därför att också få fatt i det här lärandet och för mig och för vårdnadshavare och för sig själva framförallt synliggöra lärandet som pågår på fritidshem. Där har förstelärarna varit delaktiga i att ta fram en mall. Hur ska en planering se ut? Så att vi inte bara får med görandet utan varför och "huret” också med tydlig koppling till läroplanens uppdrag. Så det är 


\section{VENUE}

väl ett policydokument hos oss eller blivande i alla fall (Intervju med rektor vid skola $\mathrm{H})$.

Rektorn antydde också att denna typ av dokumentation är något nytt på detta fritidshem och pekade på betydelsen av att synliggöra lärandet för olika aktörer. Förstelärarna har här fått en framträdande roll även inom fritidshem. Läraren på ett annat fritidshem menade på liknande sätt att de utgår från läroplanen för att kunna utvärdera sin verksamhet. Denna lärare pratade om "kompislek" som en central förmåga att utveckla och utvärdera.

Lärare 1: Som vi jobbar nu med kompislek till exempel. Det är ju samarbete och utveckla olika förmågor och där kan du ju plocka bitar ur det här, koppla till det [läroplanen]. Så där är ju fritids blivit mycket bättre på sista åren tycker jag. Att man visar att man har ett mål som vi utvärderar (Intervju med lärare 1 vid skola T).

Rektorn (vid skola $\mathrm{H}$ ) påpekade vidare vikten av att eleverna själva är aktiva i dokumentationen genom användande av så kallade lärplattor. Dessa används bland annat till att visa upp för föräldrar vad man som elev gjort under dagen.

Rektor: Ja fast de [eleverna] dokumenterar ju. På något vis tänker jag att man har ritat eller gjort ett stort bygge som man själv väljer att jag hämtar plattan och fotograferar mitt bygge för att kunna visa mamma och pappa när vi hämtar. Då är det en dokumentation av min dag på fritids (Intervju med rektor vid skola $\mathrm{H})$.

Läraren på fritidshemmet i den lilla kommun som vi intervjuat uttryckte att det framför allt är tre mål som de fokuserar, nämligen trygghet, arbetsro och kamratskap. Viktigt för att nå dessa mål är det systematiska kvalitetsarbete som de håller på att utarbeta på fritidshemmet.

Lärare 2: Sen har vi jobbat fram ett kvalitetsarbete. Det finns ett uppföljningssystem som har funkat i ett år här i kommunen med systematiskt kvalitetsarbete på fritidshemmen. Men det är jättelite snart, och då fanns det ju 15 mål eller något. Så nu har vi jobbat i chefsgruppen då så att /.../ vår skolchef då med politikerna så det är tre mål för fritidshemmen som ska utvecklas. Och det är trygghet, det är arbetsro och vad är då arbetsro på fritids håller vi på och diskuterar här. Och sen kamratskap och där har jag varit oerhört drivande för det. Det finns ju tre delar, ja det där kan du ju bättre än mig, men tre delar som är viktiga för att ungar ska klara sig i livet. Och då är kamratskap ett och det jobbar man inte med och man blir inte kamrater i en klass hur som helst. Så det har vi fått i uppdrag och det har vi påbörjat i väldigt liten 


\section{VENUE}

skala nu, men nu var vi på studiebesök nere i [stad i Mellansverige] till några som kommit längre med systematiskt kvalitetsarbete, så det är på G. (Intervju med lärare 2 vid skola $S$ ).

Gemensamt för dessa lärares och rektorers beskrivningar av arbetet med olika reformer är betydelsen av att synliggöra, dokumentera och visa upp lärandet på olika sätt. Det framträder en bild av att det redan finns flera lager av reformer som håller på att tolkas och översättas på skilda sätt i olika kontexter och att den nya läroplanen således inte kommer att landa i ett 'reform-vacuum' utan tvärtom i en stor reformträngsel - grovt räknat 35 stycken bara i de få fritidshem som vi besökt.

\section{Implikationer - vad betyder en reformträngsel för fritidshemmets verksamhet?}

Genom att lyssna på lärares och rektorers berättelser som vad som görs på fritidshem kan vi konstatera att det finns en trängsel av olika reformer. Reformerna pekar bland annat på ett ökat fokus kring att synliggöra lärandet, dokumentera, utvärdera och visa upp lärande för olika aktörer i och utanför skolan. Även om många av de aktiviteter som genomförs på fritidshem kan härröra ur en och samma formulering från läroplanen så menar vi att det har skett och sker en förändring på fritidshem idag i termer av hur lärare pratar om vikten av att dokumentera lärandet, utvärdera och visa upp skilda aktiviteter för olika aktörer. Människors agerande i skolan har en avgörande betydelse för hur reformer och villkor i skolan tar form, vilket kan studeras genom deras berättelser om sina erfarenheter och genom de dokument de formulerar. Av särskilt intresse i detta projekt är vilka konsekvenser den nya läroplanen, men också andra reformer på mer lokal nivå, får för lärare på fritidshem. Denna reformträngsel menar vi får konsekvenser för verksamheten på fritidshem men också för de aktörer - lärare såväl som elever- som vistas där.

\section{Referenser}

Lager, K. (2015). I spänningsfältet mellan kontroll och utveckling: en policystudie av systematiskt kvalitetsarbete i kommunen, förskolan och fritidshemmet. Diss. (sammanfattning) Göteborg: Göteborgs universitet, 2015. Göteborg.

Skolverket, (2011). Läroplan för grundskolan, förskoleklassen och fritidshemmet 2011(reviderad 2015). 


\section{VENUE}

Skolverket, (2014). Skolverkets allmänna råd med kommentarer. Fritidshem. Skolverket. Stockholm.

Skolverket, (2015). Regeringsredovisning: förslag till text i Lgr11 om fritidshemmet. Dnr: 2015:201. 